\title{
Adult autoimmune enteropathy presenting initially with acquired Acrodermatitis Enteropathica: a case report
}

\author{
Erina Lie ${ }^{1 *}$ D, Sarah Sung ${ }^{2}$ and Steven Hoseong Yang ${ }^{3}$
}

\begin{abstract}
Background: Acrodermatitis enteropathica (AE) is a rare dermatitis secondary to zinc deficiency most commonly seen as an inherited disease in infants. In the last decade, increased number of reports have been published on the acquired form that presents in adulthood. Unlike its inherited counterpart, acquired AE (AAE) is often secondary to underlying pathologic or iatrogenic etiologies that interfere with nutritional absorption, such as inflammatory bowel disease or alcoholism. Various gastrointestinal pathologies have been associated with AAE, but there is currently no report on its association with adult autoimmune enteropathy (AIE), a rare gastrointestinal disorder commonly seen in infants, with limited cases reported in adults. Here we present a case in which AAE was the initial clinical manifestation in an adult patient subsequently diagnosed with AIE.

Case presentation: A 41-year-old African American female presented to our emergency department at the Johns Hopkins Hospital with several months of progressively worsening dermatitis in the legs and acral regions, along with worsening symptoms of diarrhea, alopecia, poor oral intake, lethargy, hematochezia, peripheral edema, and weight loss. Our dermatology team was consulted given a presentation of exquisitely tender, erythematous, and diffusely desquamating skin lesions in the setting of two prior outside hospitalizations in the last 3 months with the same dermatitis that was refractory to topical and oral corticosteroids. Low serum zinc level and positive response to zinc supplementation confirmed the diagnosis of AAE. However, persistent hypovitaminosis and mineral deficiency despite aggressive nutritional supplementation prompted further investigation for an underlying malabsorption etiology. Jejunal biopsy and associated autoantibodies confirmed a diagnosis of adult AIE.

Conclusion: This case highlights the fact that adult AIE can present initially with clinical findings of AE. While proper zinc supplementation can resolve the latter, recognizing this association can trigger earlier diagnosis, minimize unnecessary tests, and establish earlier intervention to improve quality of life and prevent recurrence of AAE. The case also highlights the importance of collaboration between general and subspecialist physicians in identifying a primary etiology to a secondary clinical presentation. This report can be beneficial to general internists and emergency physicians, as much as it can be to dermatologists, rheumatologists, and gastroenterologists.
\end{abstract}

Keywords: Acrodermatitis enteropathica, Zinc deficiency, Dermatitis, Autoimmune enteropathy, Malnutrition, Case report

\footnotetext{
* Correspondence: elie1@jhmi.edu

'Department of Dermatology, Johns Hopkins University School of Medicine,

200 North Wolfe Street, Unit 2106, Baltimore, MD 21287, USA

Full list of author information is available at the end of the article
} 


\section{Background}

Acrodermatitis enteropathica (AE) is a condition caused by zinc deficiency that classically presents with periorificial and acral papulosquamous eruptions accompanied by diarrhea and alopecia [1]. The inherited form, a rare autosomal recessive trait due to mutations in the gene SCL39A4 on chromosome 8q24.3 [2], is more common and typically seen in infants. However, in the last decade, we have witnessed an increased number of reports on acquired $\mathrm{AE}$ affecting adults and the elderlies particularly in association with anorexia nervosa, alcoholism, bariatric surgery, total parenteral nutrition, nephropathy, inflammatory bowel disease (IBD), blind loop syndrome, and celiac disease [3-7]. Here we present a novel case of acquired $\mathrm{AE}$ as an initial presentation of autoimmune enteropathy (AIE), itself a rare gastrointestinal disorder characterized by refractory diarrhea and malnutrition that affects less than $1 / 100,000$ infants, with limited case reports in adults $[8,9]$.

\section{Case presentation}

A 41-year-old African American female presented with a 4-month history of progressive, exquisitely tender, nonpruritic leg and acral dermatitis, diarrhea, alopecia, poor oral intake, lethargy, hematochezia, lower extremity edema, and 22lbs of unintentional weight loss. Physical examination revealed erythema and desquamation along the extremities (Fig. 1a), plantar feet (Fig. 1b), and palmar hands (Fig. 1c), paronychia, angular cheilitis with lip fissure, glossitis, ulcerations and satellite erosions in the lumbosacral, perianal, and perineal regions (Fig. 1d), and diffuse alopecia of the scalp.
Her symptoms began initially with dysgeusia, lower extremity edema, along with erythematous cutaneous eruption and desquamation of the lower extremities and acral region that was refractory to topical triamcinolone $0.1 \%$ ointment. By the second month, her symptoms persisted with additional blurring of vision, xerostomia, diarrhea, hematochezia, anorexia, and thrombocytopenia that necessitated a 22-day hospitalization. She was diagnosed with immune thrombocytopenic purpura (ITP) and non-alcoholic steatohepatitis, confirmed by positive anti-platelet antibody and liver biopsy, respectively. She was started on prednisone $60 \mathrm{mg}$ and discharged with a 4-week taper.

By the third month, specifically a day after discontinuing prednisone, she noted recurring edema in her lower extremities that progressed rapidly to painful desquamative and vesiculobullous lesions resulting in a second hospitalization. Skin biopsy revealed mild spongiotic dermatitis with alternating hyperparakeratosis and papillary dermal edema without evidence of vasculitis, systemic lupus erythematous, or autoimmune bullous disease on immunofluorescence. She was diagnosed with an eczematous dermatitis and discharged with another 4-week prednisone taper. During this hospitalization, she also developed sacral pressure ulcer. Two weeks after this last hospitalization, persistent edema, a nonhealing sacral ulcer, and worsening desquamative plaques eventually brought her to our institution for the first time with the presentation described above.

Repeat skin biopsy of the right medial malleolus demonstrated an unremarkable epidermis, slightly ectatic superficial dermal vessels with surrounding focal rare

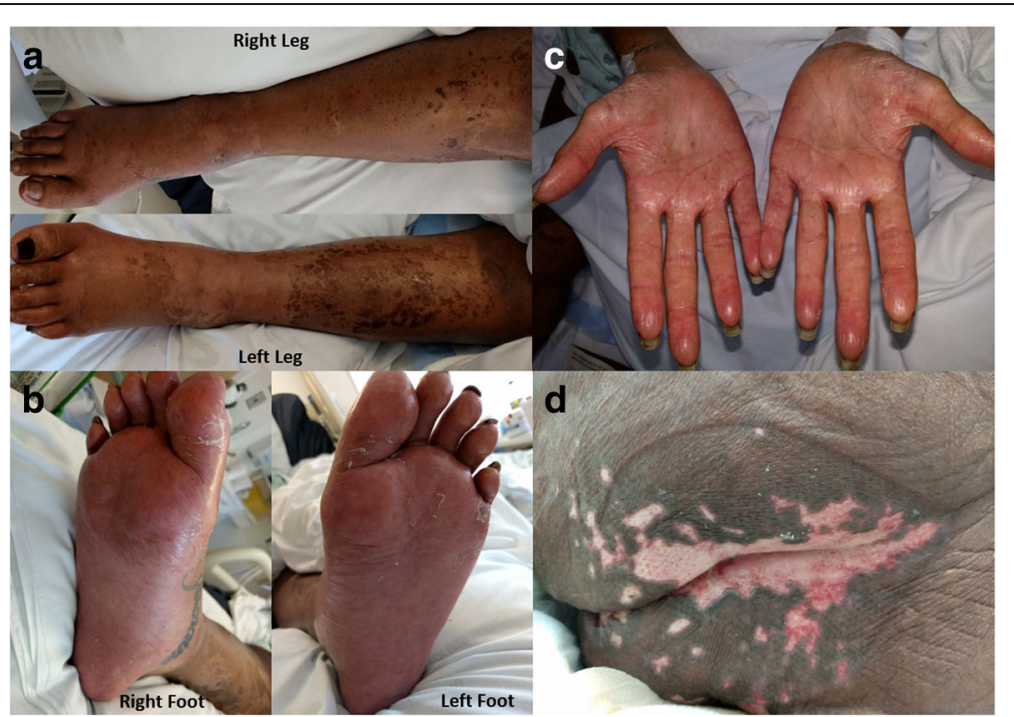

Fig. 1 Acquired acrodermatitis enteropathica - Day 2 of admission. Legend: Desquamative erythematous patches with edema involving bilateral lower extremities (a) and plantar feet (b). Erythema with subtle desquamation on bilateral palmar hands (c). Ulceration and satellite erosions in the lumbosacral, perianal, and perineal region (d) 
lymphocytes and rare extravasated red blood cells, without evidence of erythema multiforme or StevensJohnson Syndrome/Toxic Epidermal Necrolysis (SJS/ TEN). However, her zinc level was found to be $30 \mu \mathrm{g} / \mathrm{dL}$ (normal: 60-130 $\mu \mathrm{g} / \mathrm{dL}$ ), which improved after 20-days of intravenous supplementation of zinc sulphate $220 \mathrm{mg}$ thrice daily (Table 1). Clinically, her cutaneous findings and gastrointestinal function also showed marked improvements (Fig. 2a-b). Her dermatologic findings and responsiveness to zinc supplement confirmed the diagnosis of acquired AE.

Notably, she had severe hypovitaminosis and mineral deficiencies that improved only minimally despite repletion (Table 1). Given a newly-diagnosed ITP, hematochezia, sicca syndrome, and persistently low pre-albumin level, she underwent an extensive additional work-up to investigate the possibility of an underlying etiology contributing to her nutritional deficiency. Her diagnostic work-up included broad titer analyses (Tables 2 and 3), blood/urine/stool analyses, esophagogastroduodenoscopy with biopsy, and colonoscopy with biopsy. Negative biopsy findings and associated autoantibody, viral, fungal, and bacterial titers ruled out the more common autoimmune and infectious causes of malabsorption, such as IBD and celiac disease (Table 3). Our patient was eventually diagnosed with AIE based on jejunal biopsy findings of mild increase in intraepithelial lymphocytes, crypt apoptosis, reactive epithelial changes, and mild mononuclear and neutrophil expansion of the lamina propria, supported by positive anti-gastric parietal cell and anti-smooth muscle autoantibodies. Other reported associations with AIE, including sicca syndrome, gastritis, nephrotic syndrome, autoimmune hepatitis, and chronic pancreatitis, were also present in this patient, further supporting the diagnosis. She was discharged after 20 days with central parenteral nutrition (CPN), prednisone $15 \mathrm{mg}$ daily, and close outpatient follow-up with markedly improved dermatologic findings. Follow-up visit at our dermatology clinic 15 weeks later was unremarkable with no recurrence of cutaneous findings (Table 4). At the time of manuscript submission, patient has remained stable without further hospitalization nor recurrence of symptoms. She continued to require CPN and oral supplements with weekly nutritionist monitoring and periodic gastroenterology follow-up.

\section{Discussion}

Zinc is an essential mineral that plays crucial roles in metabolism, development, tissue repair, and cell proliferation, including proper maturation of basal keratinocytes

Table 1 Serum nutrient levels (values at initial presentation and prior to discharge) and nutrient repletion regimens during the 20 days of hospitalization

\begin{tabular}{|c|c|c|c|c|}
\hline Serum Level & Initial Value & Value after 15-20 Days & Reference Range & Repletion \\
\hline Pre-albumin ${ }^{\mathrm{ab}}$ & $7 \mathrm{mg} / \mathrm{dL}$ & $7 \mathrm{mg} / \mathrm{dL}$ & $18-38 \mathrm{mg} / \mathrm{dL}$ & - \\
\hline Albumin $^{\mathrm{ab}}$ & $1.5 \mathrm{~g} / \mathrm{dL}$ & $2.3 \mathrm{~g} / \mathrm{dL}$ & $3.5-5.3 \mathrm{~g} / \mathrm{dL}$ & - \\
\hline Ionized Calcium $^{a}$ & $1.07 \mathrm{mmol} / \mathrm{L}$ & $1.20 \mathrm{mmol} / \mathrm{L}$ & $1.13-1.32 \mathrm{mmol} / \mathrm{L}$ & - \\
\hline Copper $^{\mathrm{ab}}$ & $51 \mu \mathrm{g} / \mathrm{dL}$ & $67 \mu \mathrm{g} / \mathrm{dL}$ & $70-175 \mu \mathrm{g} / \mathrm{dL}$ & 2 mg PO daily \\
\hline Iron $^{\mathrm{ab}}$ & $48 \mu \mathrm{g} / \mathrm{dL}$ & $44 \mu \mathrm{g} / \mathrm{dL}$ & $50-170 \mu \mathrm{g} / \mathrm{dL}$ & 325 mg PO with meals \\
\hline Magnesium & $2.0 \mathrm{mg} / \mathrm{dL}$ & $1.8 \mathrm{mg} / \mathrm{dL}$ & $1.6-2.4 \mathrm{mg} / \mathrm{dL}$ & - \\
\hline Phosphorus $^{a}$ & $2.5 \mathrm{mg} / \mathrm{dL}$ & $3.0 \mathrm{mg} / \mathrm{dL}$ & $2.7-4.5 \mathrm{mg} / \mathrm{dL}$ & - \\
\hline Selenium $^{\mathrm{ab}}$ & $44 \mu \mathrm{g} / \mathrm{dL}$ & $48 \mu \mathrm{g} / \mathrm{dL}$ & $63-160 \mu \mathrm{g} / \mathrm{dL}$ & 50mcg PO daily \\
\hline $\operatorname{Zinc}^{\mathrm{ab}}$ & $30 \mu \mathrm{g} / \mathrm{dL}$ & $52 \mu \mathrm{g} / \mathrm{dL}$ & $60-130 \mu \mathrm{g} / \mathrm{dL}$ & $220 \mathrm{mg}$ PO TID \\
\hline Vit $A^{a b}$ & $11 \mu \mathrm{g} / \mathrm{dL}$ & $14 \mu \mathrm{g} / \mathrm{dL}$ & $38-98 \mu \mathrm{g} / \mathrm{dL}$ & 200,000 IU PO ×3 \\
\hline Vit B1 & $109 \mathrm{nmol} / \mathrm{L}$ & - & $78-185 \mathrm{nmol} / \mathrm{L}$ & 100 mg PO daily \\
\hline Vit B3/Niacin & $<20 \mathrm{ng} / \mathrm{mL}$ & - & Variable & 100 mg PO qhs \\
\hline Vit B6 ${ }^{\mathrm{ab}}$ & $<2.0 \mathrm{ng} / \mathrm{mL}$ & - & $2.1-21.7 \mathrm{ng} / \mathrm{mL}$ & 100 mg PO daily \\
\hline Vit B9/Folate & 1743 ng/dL & $1578 \mathrm{ng} / \mathrm{dL}$ & $>498 \mathrm{ng} / \mathrm{dL}$ & - \\
\hline Vit B12 & $1161 \mathrm{pg} / \mathrm{mL}$ & $1592 \mathrm{pg} / \mathrm{mL}$ & $211-946 \mathrm{pg} / \mathrm{mL}$ & - \\
\hline Vit D total ${ }^{\mathrm{ab}}$ & $18 \mathrm{ng} / \mathrm{mL}$ & $8 \mathrm{ng} / \mathrm{mL}$ & $30-100 \mathrm{ng} / \mathrm{mL}$ & $\begin{array}{l}\text { Vit } D_{2}: 50,000 \text { IU PO q7d } \\
C^{C a C O}: 1300 \text { mg PO TID }\end{array}$ \\
\hline Vit $E-\mathbf{a}^{\mathrm{abc}}$ & $1.1 \mathrm{mg} / \mathrm{L}$ & $2.5 \mathrm{mg} / \mathrm{L}$ & $5.7-19.9$ mg/L & 100 mg PO daily \\
\hline Vit $E-\boldsymbol{\beta}^{c}$ & $0.4 \mathrm{mg} / \mathrm{L}$ & $1.0 \mathrm{mg} / \mathrm{L}$ & $\leq 4.3 \mathrm{mg} / \mathrm{L}$ & 100 mg PO daily \\
\hline Vit K & $84 \mathrm{pg} / \mathrm{mL}$ & - & 80-1160 pg/mL & - \\
\hline
\end{tabular}

anitial value is below normal

${ }^{b}$ Latest value prior to discharge is below normal

c $a=$ alpha tocopherol; $\beta=$ beta tocopherol

${ }^{d} 200 \mathrm{mg}$ zinc sulphate tablet contains $50 \mathrm{mg}$ of elemental zinc 


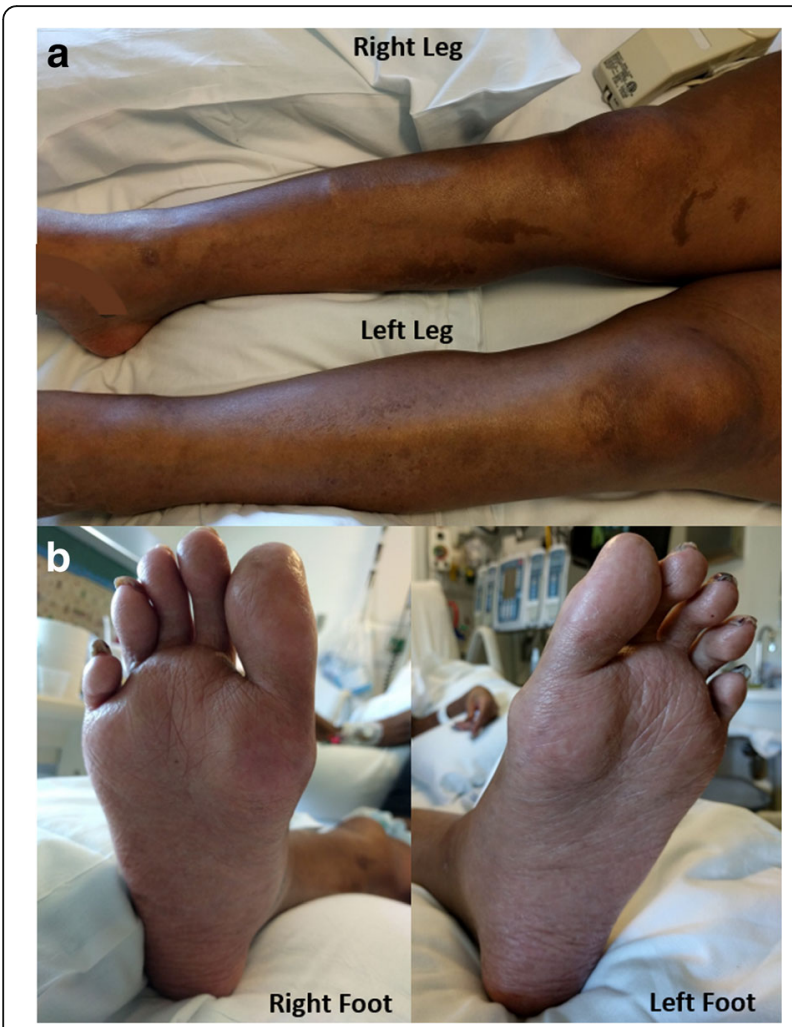

Fig. 2 Acquired acrodermatitis enteropathica - Day 20 of admission. Legend: Resolution of edema, erythema, and desquamation in the bilateral lower extremities (a) and plantar feet (b)

[1]. Zinc deficiency, manifested in $\mathrm{AE}$, can be acquired through decreased intake (e.g. vegetarianism, alcoholism), increased demand (e.g. pregnancy), intestinal malabsorption (e.g. IBD, gastric bypass), increased urinary loss (e.g. diuretics), or state of hypoalbuminemia since zinc binds albumin in the circulation (e.g. liver damage) [1]. Aside from the triad of dermatitis, diarrhea, and alopecia, symptoms of $\mathrm{AE}$ can also include angular cheilitis followed by paronychia, glossitis, ophthalmologic disturbances, poor wound healing, anemia, dysgeusia, dysosmia, and profound lethargy [1, 10]. Differential diagnoses include necrolytic migratory erythema, SJS/

Table 2 Abnormal titre results for autoantibodies, viruses, fungi, and bacterial toxins

\begin{tabular}{lll}
\hline Titre Names & Results & Reference Range \\
\hline Abnormal results: & & \\
Anti-Ro (SSA) Ab & Moderate Positive & Negative \\
Gastric parietal cell Ab & 55.5 units & $\leq 20$ units = Negative \\
Smooth muscle Ab & Positive & Negative \\
C3, serum & $71 \mathrm{mg} / \mathrm{dL}$ & $79-251 \mathrm{mg} / \mathrm{dL}$ \\
CMV viral load & $2640 \mathrm{IU} / \mathrm{mL}$ & $<137 \mathrm{IJ} / \mathrm{mL}$ \\
\hline Ab $=$ & &
\end{tabular}

$A b=$ antibody

$C M V=$ Cytomegalovirus
Table 3 Titre results within normal range for autoantibodies, viruses, fungi, and bacterial toxins

\begin{tabular}{|c|c|c|}
\hline \multicolumn{3}{|l|}{ Titre Names } \\
\hline $\begin{array}{l}\text { Alpha-1 anti-trypsin, } \\
\text { stool, 24-h }\end{array}$ & Anti-Jo-1 Ab & Direct anti-globulin test \\
\hline p-ANCA & Anti-La (SSB) Ab & $\begin{array}{l}\text { Glomerular basement } \\
\text { membrane } \mathrm{Ab}\end{array}$ \\
\hline C-ANCA & $\begin{array}{l}\text { Anti-nuclear Ab } \\
\text { (ANA) }\end{array}$ & Islet cell Ab \\
\hline $\begin{array}{l}\text { Anti-cardiolipin Ab, } \\
\text { lgG }\end{array}$ & Anti-Scl70 Ab & $\begin{array}{l}\text { Liver-kidney microsomal } \\
\text { Ab }\end{array}$ \\
\hline $\begin{array}{l}\text { Anti-cardiolipin Ab, } \\
\text { lgM }\end{array}$ & Anti-Smith $\mathrm{Ab}$ & Mitochondrial $\mathrm{Ab}$ \\
\hline $\begin{array}{l}\text { Anti-cardiolipin Ab, } \\
\lg A\end{array}$ & Anti-URP Ab & Rheumatoid factor \\
\hline Anti-dsDNA Ab & $\begin{array}{l}\text { Beta-2 glycoprotein } \\
\text { Ab, IgG }\end{array}$ & Thyroglobulin Ab \\
\hline $\begin{array}{l}\text { Anti-enterocyte Ab, } \\
\text { lgG }\end{array}$ & $\begin{array}{l}\text { Beta-2 glycoprotein } \\
\text { Ab, IgM }\end{array}$ & $\begin{array}{l}\text { Thyroid peroxidase } \\
\text { microsomal Ab }\end{array}$ \\
\hline $\begin{array}{l}\text { Anti-enterocyte Ab, } \\
\text { lgM }\end{array}$ & $\begin{array}{l}\text { Beta-2 glycoprotein } \\
\text { Ab, IgA }\end{array}$ & $\begin{array}{l}\text { Tissue transglutaminase, } \\
\lg A\end{array}$ \\
\hline $\begin{array}{l}\text { Anti-enterocyte Ab, } \\
\lg A\end{array}$ & $\begin{array}{l}\text { Cyclic citrul peptide } \\
\text { Ab }\end{array}$ & TSH receptor $A b$ \\
\hline C4, serum & EBV viral load & $\begin{array}{l}\text { C.difficile toxin B gene } \\
\text { NAT }\end{array}$ \\
\hline \multirow[t]{2}{*}{$\mathrm{CH} 50$, serum } & (1-3)-Beta-D-Glucan & Diphtheria antitoxin Ab \\
\hline & $\begin{array}{l}\text { Galactomannan, } \\
\text { serum }\end{array}$ & \\
\hline \multicolumn{3}{|c|}{$\begin{array}{l}A b=\text { antibody } \\
p-A N C A=\text { perinuclear anti-neutrophilic cytoplasmic antibody } \\
C-A N C A=\text { cytoplasmic anti-neutrophilic cytoplasmic antibody } \\
A N A=\text { Antinuclear Antibody } \\
E B V=\text { Epstein-Barr Virus } \\
T S H=\text { Thyroid-Stimulating Hormone }\end{array}$} \\
\hline
\end{tabular}

TEN, blistering diseases, epidermolysis bullosa, and pellagra $[6,10]$. Histopathologic findings are typically indistinguishable from other forms of malnutrition dermatitis. Pathognomonic feature of fully-developed necrolysis has been reported, which involves cytoplasmic pallor, vacuolization, ballooning degeneration, and confluent epidermal parakeratosis [1]. More commonly, however, histopathology is either non-specific, such as found in our patient, or displays upper epidermal pallor with psoriasiform hyperplasia and confluent parakeratosis $[1,11]$. Diagnosis is made by clinical findings subsequently responsive to zinc supplementation supported by findings of low plasma or serum zinc concentration and/or suggestive histologicfindings $[1,11]$.

AIE is a rare cause of intractable diarrhea and malnutrition associated with gut autoantibodies and predisposition to autoimmunity $[9,12]$. Histologically, there is partial or complete small bowel villous blunting, deep crypt lymphocytosis, increased crypt apoptosis, and minimal intraepithelial lymphocytosis. Diagnostic criteria necessitate chronic diarrhea ( $>6$ weeks) with malabsorption refractory 
Table 4 Case report timeline

\begin{tabular}{|c|c|}
\hline Chronology & Timeline Description \\
\hline $\mathrm{T}_{0}-4$ months & $\begin{array}{l}\text { Clinical presentation: dysgeusia, lower extremity edema, } \\
\text { and cutaneous eruption and erythema of the lower } \\
\text { extremities and acral region with desquamation } \\
\text { Management: refractory to topical triamcinolone } 0.1 \% \\
\text { ointment }\end{array}$ \\
\hline $\mathrm{T}_{0}-3$ months & $\begin{array}{l}\text { Clinical presentation: symptoms persisted with } \\
\text { additional blurring of vision, xerostomia, diarrhea, } \\
\text { hematochezia, anorexia, and thrombocytopenia } \\
\text { Diagnosis: immune thrombocytopenic purpura (ITP) and } \\
\text { non-alcoholic steatohepatitis } \\
\text { Management: 22-day hospitalization, prednisone } 60 \mathrm{mg} \\
\text { and discharged with a 4-week taper }\end{array}$ \\
\hline $\mathrm{T}_{0}-2$ months & $\begin{array}{l}\text { Clinical presentation: recurring edema in the lower } \\
\text { extremities progressing rapidly to painful desquamative } \\
\text { and vesiculobullous lesions } \\
\text { Diagnosis: eczematous dermatitis } \\
\text { Diagnostic tests: skin biopsy } \\
\text { Management: second hospitalization, discharged with } \\
\text { another 4-week prednisone taper } \\
\text { Comments: developed sacral pressure ulcer }\end{array}$ \\
\hline $\mathrm{T}_{0}$ & $\begin{array}{l}\text { Clinical presentation: persistent edema, non-healing sa- } \\
\text { cral ulcer, worsening desquamative plaques } \\
\text { Diagnosis: acquired acrodermatitis enteropathica and } \\
\text { severe nutrition deficiency } \\
\text { Diagnostic tests: skin biopsy of the right medial } \\
\text { malleolus, broad titre analyses, } \\
\text { esophagogastroduodenoscopy and colonoscopy with } \\
\text { biopsy } \\
\text { Management: broad nutrition repletion }\end{array}$ \\
\hline $\mathrm{T}_{0}+3$ weeks & $\begin{array}{l}\text { Clinical presentation: marked improvements of } \\
\text { cutaneous findings and gastrointestinal function } \\
\text { Diagnosis: adult autoimmune enteropathy } \\
\text { Management: discharged with central parenteral } \\
\text { nutrition (CPN), prednisone } 15 \mathrm{mg} \text { daily, and close } \\
\text { outpatient follow-up }\end{array}$ \\
\hline $\mathrm{T}_{0}+4$ months & $\begin{array}{l}\text { Clinical presentation: outpatient follow-up with unre- } \\
\text { markable cutaneous findings } \\
\text { Management: continue CPN and oral supplements, } \\
\text { close outpatient follow-up with gastroenterology and } \\
\text { nutrition }\end{array}$ \\
\hline
\end{tabular}

to dietary modification, presence of autoantibodies, no known immunodeficiency, and histologic findings that exclude other causes of villous atrophy [9]. Autoantibodies associated with AIE include antibodies against enterocytes, goblet cells, pancreatic islets, DNA, thyroglobulin, smooth muscle, and gastric parietal cell, the latter two of which were present in our patient [9].

Zinc, and other nutritional, deficiencies in adults are often a manifestation of an underlying malabsorptive etiology. With the rise of chronic diseases in adults, it has become increasingly difficult to determine the main cause of malabsorption in a patient with multiple chronic illnesses that individually predisposes to malnutrition. Clinical history and continuity of care become critical for establishing a clear timeline of symptoms onset and associations. Our patient had a 10-year history of Roux-en-Y gastric bypass with concurrent vegetarianism, pregnancy complicated by gestational hypertension and opioid dependence 2 years prior, and chronic hypertension treated with diuretics, each individual risk factors for zinc deficiency. However, zinc is not stored in large amount in the body [13], so given the chronicity of these medical issues and no history of acquired $\mathrm{AE}$, they were unlikely to be the cause of her current presentation. The timing of hematochezia, sicca syndrome, and ITP closely following the onset of AE symptoms 4 months ago suggested that she likely developed AIE that presented initially with cutaneous findings of zinc deficiency secondary to gastrointestinal dysfunction.

Acquired AE has a very good prognosis with prompt intravenous supplementation starting at $3 \mathrm{mg} / \mathrm{kg} /$ day of elemental zinc. Recurrence is likely with untreated underlying conditions, so serum/plasma zinc levels and zinc-dependent enzyme levels should be monitored every 3 to 6 months. It is likewise advisable to monitor copper level and supplement if necessary since zinc can interfere with copper absorption [1, 14]. Reports have shown dramatic clinical improvements within the first few days to weeks of zinc supplementation, often ahead of normalization in serum zinc level $[1,3-7,10]$, as illustrated in our patient.

\section{Conclusion}

In summary, clinicians should maintain a low threshold of suspicion for acquired $\mathrm{AE}$ and check for zinc deficiency in adult patients with associated risk factors for malnutrition who presents with a confluence of relevant dermatologic findings that are refractory to standard therapy. Additionally, clinicians should also consider the possibility of a broader nutritional deficiency and an underlying primary malabsorption etiology. In investigating the latter for a patient with acquired $\mathrm{AE}$, recognition of the association with adult AIE can benefit patient care by triggering earlier diagnosis, minimizing unnecessary tests, and establishing earlier interventions that can improve a patient's quality of life and prevent the recurrence of acquired AE.

\section{Abbreviations \\ AE: Acrodermatitis enteropathica; AIE: Autoimmune enteropathy; CPN: Central parenteral nutrition; IBD: Inflammatory bowel disease; ITP: Immune thrombocytopenic purpura; SJS: Stevens-Johnson Syndrome; TEN: Toxic epidermal necrolysis}

\section{Acknowledgements}

Not applicable. There were no other contributors to this article.

Funding

There are no funding sources for this case report.

\section{Availability of data and materials}

All laboratory, imaging, and study data relevant to this case report can be found in the "Case presentation" section of this article. 


\section{Authors' contributions}

EL performed data collection, photography of clinical images, and was the main contributor in drafting and revising the manuscript. SS was the primary dermatology resident physician during the patient's hospitalization, served as interdisciplinary liaison with the patient's other care teams (e.g. internal medicine, rheumatology), and was a key contributor to the revisions of the manuscript. SHY was the attending-in-charge of the care of the patient and a key contributor to the revisions of the manuscript. All authors read and approved the final manuscript.

\section{Authors' information}

EL is a fourth year medical student at the Johns Hopkins Hospital currently engaged in a year of research with the Department of Dermatology. SS was a fourth year dermatology resident at the Johns Hopkins Hospital, she has completed her training as of August 2016 and is currently a private practitioner in Seattle, WA. SHY is an Assistant Director of the Cutaneous Translational Research Program and Assistant Professor in the Department of Dermatology at the Johns Hopkins Hospital.

\section{Competing interests}

The authors declare that they have no competing interests.

\section{Consent for publication}

Written informed consent was obtained from the patient for publication of this case report and accompanying images. A copy of written consent is available for review by the Editor-in-Chief of this journal.

\section{Ethics approval and consent to participate}

Not applicable.

\section{Author details}

'Department of Dermatology, Johns Hopkins University School of Medicine, 200 North Wolfe Street, Unit 2106, Baltimore, MD 21287, USA. ²Department of Dermatology, Johns Hopkins University School of Medicine, 1550 Orleans Street, Koch CRB II, Unit 206, Baltimore, MD 21231, USA. ${ }^{3}$ Department of Dermatology, Johns Hopkins University School of Medicine, 1550 Orleans Street, Koch CRB II, Unit 206, Baltimore, MD 21231, USA.

Received: 14 December 2016 Accepted: 5 May 2017

Published online: 18 May 2017

\section{References}

1. Maverakis E, Fung MA, Lynch PJ, et al. Acrodermatitis enteropathica and an overview of zinc metabolism. J Am Acad Dermatol. 2007;56(1):116-24.

2. Wang K, Pugh EW, Griffen S, et al. Homozygosity mapping places the acrodermatitis enteropathica gene on chromosomal region 8q24.3. Am J Hum Genet. 2001;68(4):1055-60.

3. Kobayashi K, Kono M, Shiraishi M. Severe acquired acrodermatitis enteropathica caused by anorexia nervosa. J Dermatol. 2016;43(4):456-7.

4. Macdonald JB, Connolly SM, DiCaudo DJ. Think zinc deficiency: acquired Acrodermatitis Enteropathica due to poor diet and common medications. Arch Dermatol. 2012;148(8):961-3.

5. Mankaney GN, Vipperla K. Images in clinical medicine. Acquired acrodermatitis enteropathica. N Engl J Med. 2014;371(1):67.

6. Lott JP, Reeve J, Ko C, Girardi M. Periorificial dermatitis and erosive inguinal plaques in a 57-year-old woman. Acquired zinc deficiency acrodermatitis enteropathica (ADE). JAMA Dermatol. 2013;149(3):357-63.

7. Weinkle AP, Patel N, Kissel R, Seminario-Vidal L. Acquired acrodermatitis enteropathica as a presenting sign of celiac disease. JAAD Case Rep. 2016; 2(3):193-5.

8. Akram S, Murray JA, Pardi DS, et al. Adult Autoimmune Enteropathy: Mayo Clinic Rochester experience. Clin Gastroenterol Hepatol. 2007;5(11):1282-90.

9. Gentile NM, Murray JA, Pardi DS. Autoimmune enteropathy: a review and update of clinical management. Curr Gastroenterol Rep. 2012;14(5):380-5.

10. Perafán-Riveros C, França LFS, Alves ACF, Sanches JA Jr. Acrodermatitis Enteropathica: case report and review of the literature. Ped Derm. 2002; 19(5):426-31.

11. Gonzalez JR, Botet MV, Sanchez JL. The histopathology of acrodermatitis enteropathica. Am J Dermatopathol. 1982;4:303-11.
12. Casis B, Fernández-Vázquez I, Barnardos E, et al. Autoimmune enteropathy in an adult with autoimmune multisystemic involvement. Scand J Gastroenterol. 2002;37(9):1012-6.

13. Food and agriculture Organization of the United Nations. Chapter 16 zinc In: Human vitamin and mineral requirements. Report of a joint FAO/WHO expert consultation. FAO, Rome. 2002. http://www.fao.org/docrep/004/ y2809e/y2809e0m.htm\#bm22.5. Accessed April 23, 2016.

14. Yuzbasiyan-Gurkan V, Grider A, Nostrant T, et al. Treatment of Wilson's disease with zinc: $X$, intestinal metallothionein induction. J Lab Clin Med. 1992;120:380-6.

\section{Submit your next manuscript to BioMed Central and we will help you at every step:}

- We accept pre-submission inquiries

- Our selector tool helps you to find the most relevant journal

- We provide round the clock customer support

- Convenient online submission

- Thorough peer review

- Inclusion in PubMed and all major indexing services

- Maximum visibility for your research

Submit your manuscript at www.biomedcentral.com/submit
) Biomed Central 